TRENDS IN HYDROZOAN BIOLOGY - IV. C.E. MILLS, F. BOERO, A. MIGOTTO and J.M. GILI (eds.)

\title{
Ecological characteristics of the Mljet Island seawater lakes (South Adriatic Sea) with special reference to their resident populations of medusae*
}

\author{
A. BENOVIĆ, D. LUČIĆ, V. ONOFRI, M. PEHARDA, M. CARIĆ, N. JASPRICA \\ and S. BOBANOVIĆ-ĆOLIĆ \\ Institute of Oceanography and Fisheries, Laboratories Dubrovnik, P.O.Box 83. HR-20101 Dubrovnik, Croatia.
}

\begin{abstract}
SUMMARY: Ecological properties and distribution and abundance of medusae were studied over an 18-month period in the Mljet Island seawater lakes, south-east Croatia. Strong stratification during the summer differentiates these lakes from the oligotrophic South Adriatic ecosystem. The lakes are designated as a moderately eutrophicated ecosystem. Very small numbers of hydromedusae were noted, representing only the Anthomedusae and Leptomedusae. A new species of the genus Tima was found in considerable numbers of individuals. High abundance of the scyphomedusa Aurelia sp. was observed throughout the year. This species differs in terms of genetic divergence from Aurelia aurita found elsewhere in the Mediterranean and could be attributed to the boreal origin.
\end{abstract}

Key words: seawater lake, stratification, medusae, Tima, Aurelia, South Adriatic.

\section{INTRODUCTION}

The island of Mljet is an offshore south Adriatic island that extends in a NW-SE direction (Fig.1). The $8-10 \mathrm{~km}$ wide Mljet Canal separates it from the mainland. As the southernmost island in the Adriatic, Mljet is directly exposed to the incoming Ionian sea current and is influenced by it (Zore-Armanda et al., 1991; The POEM Group, 1992). Plankton community structure and density values in the south Adriatic correspond to the general values for oligotrophic eastern Mediterranean waters (Viličić, 1985, 1991; Benović and Lučić, 1996; Kršinić, 1998; Hure and Kršinić, 1998).

The seawater lakes "Veliko Jezero" and "Malo Jezero" are located on the western part of Mljet

\footnotetext{
*Received February 26, 1999. Accepted October 1, 1999.
}

Island and are connected to the surrounding sea from the south. They are natural phenomena of karstic depressions that were filled by seawater about 4200 years B.P. (M. Juračić and V. Onofri, unpublished) and 7000 years B.P. (Seibold, 1958; Schmidt, 1993), respectively. The first scientific data on the marine fauna and hydrographic conditions of the Mljet lakes were published in 1935 (Ercegović, 1935). More intensive research was conducted in the period from 1951 to 1955 and from 1985 to 1986 (see: Vučetić, 1995; Benović and Onofri, 1995).

Previous scientific research in the Mljet lakes only partially included data on medusae and made no attempt to estimate their importance in structuring the plankton communities. When present in high numbers, the scyphomedusa Aurelia aurita has been shown to have a significant impact on the structure 


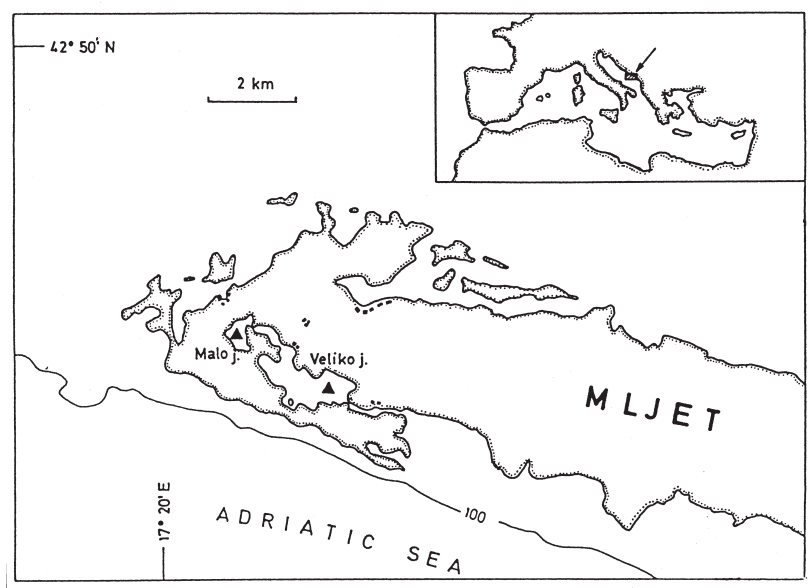

FIG. 1. - Map of the seawater Mljet lakes "Veliko jezero" (VJ) and "Malo jezero" (MJ). The black triangles indicates the deepest locations (46 $\mathrm{m}$ and $29 \mathrm{~m}$, respectively), which in $\mathrm{VJ}$ is also the most frequent swarm site for Aurelia sp.

of coastal planktonic communities by its predation on zooplankton (Shushkina and Musayeva, 1983; Behrends and Schneider, 1995; Olesen, 1995; Omori et al., 1995; Lucas, 1996; Ishii and Bamstedt, 1998). The present paper describes the physical, chemical and plankton characteristics of the Mljet seawater lakes ecosystems and relates them to the large and persistent populations of Aurelia sp. and to other medusae present there, particularly an unusual large, unidentified species of Tima.

\section{MATERIALS AND METHODS}

The study reported here was carried out from June 1997 to January 1999 in the two seawater lakes of Mljet Island. The "Veliko Jezero" (VJ) has a surface area of $1.45 \mathrm{~km}^{2}$ and maximum depth of $46 \mathrm{~m}$ while the "Malo Jezero" (MJ) has a surface area of $0.25 \mathrm{~km}^{2}$ and maximum depth of $29 \mathrm{~m}$. Narrow and shallow straits (from the outer sea to "VJ": $10 \mathrm{~m}$ wide, $2.5 \mathrm{~m}$ deep; from "VJ" to "MJ": $3 \mathrm{~m}$ wide, 0.5 $\mathrm{m}$ deep) connect the lakes with the outer southern Adriatic Sea (Fig. 1).

A multiprobe Hydrolab-Surveyor-3 was used for measuring temperature, salinity and oxygen. Samples of nutrients were collected by water bottles and determined by standard oceanographic methods (Strickland and Parsons, 1972; Grasshoff et al.1983). Zooplankton was collected by vertical tows with a $0.125 \mathrm{~mm}$ mesh Nansen plankton net and whole samples were analyzed under a stereomicroscope. All samples for plankton analyses were preserved in $2.5 \%$ neutralized formaldehyde. SCUBA diving was used during daylight and at night for the field observation and sampling of Aurelia sp. and Tima sp. Underwater recording was performed using a Camcorder Sony-DCR-VX 1000 E 3CCD DIGITAL with underwater lights and depth indicator. Video editing was performed using a PC Capture Board: Fast DVMaster with frame rates $25 \mathrm{f} / \mathrm{s}$.

For the purpose of this paper, unpublished hydrographic and SCUBA diving data from the 26th to 28th of August 1996 were included in the analysis.

Nutrients data were subjected to the analysis of variance (ANOVA) and SNK multiple range tests.

\section{RESULTS}

Temperature ranges in MJ (Fig. 2) were from a minimum of $9.7^{\circ} \mathrm{C}$ in February 1998 to a maximum of $29.4^{\circ} \mathrm{C}$ in August 1997. In VJ, temperature (Fig. 3) ranged from the constant minimum of $11.0^{\circ} \mathrm{C}$ in the bottom layers to a maximum of $28.0^{\circ} \mathrm{C}$ at the surface in July 1998. During the winter months, isothermal spreadout of values was characteristic, while in summer months a very strong thermal stratification existed in the layers between 10-15 m (MJ) and $15-20 \mathrm{~m}(\mathrm{VJ})$. A very pronounced thermocline occurred in July (VJ) and September (MJ) when in only one meter, the temperature dropped $4^{\circ} \mathrm{C}$ and $6^{\circ} \mathrm{C}$, respectively. Other months were characterized by transitive values.

Salinity ranges in MJ (Fig. 2) were between 36.5 psu in the surface layer in May 1998 and 38.2 psu $10 \mathrm{~m}$ above the bottom in June 1997. However, most values were between $37.0 \mathrm{psu}$ and $37.5 \mathrm{psu}$. In VJ (Fig. 3) salinity ranged between 36.3 psu and 39.0 psu, but most values are between 37.5 psu and 38.0 psu. High values throughout the entire water column were noted in summer months of 1997. A slight stratification with lower salinity values down to 20 $\mathrm{m}$, and minimum of $36.3 \mathrm{psu}$ at the surface were noted in 1998.

Dissolved oxygen saturation ranged from $4.3 \%$ (MJ) and 17\% (VJ) in October 1997 near the bottom, to $122 \%(\mathrm{MJ})$ and $130 \%(\mathrm{VJ})$ in August 1998 in the thermocline layers (Figs. 2 and 3). Stratification occurred during summer and autumn months. In general, dissolved oxygen and most saturation values were between $80 \%$ and $110 \%$. Though waters are well-saturated, an anoxic event in VJ was noticed briefly between 26 and 28 August 1996. During that event the strongest thermocline of $7.0^{\circ} \mathrm{C}$ was observed between 17 and $20 \mathrm{~m}$. In the layer 

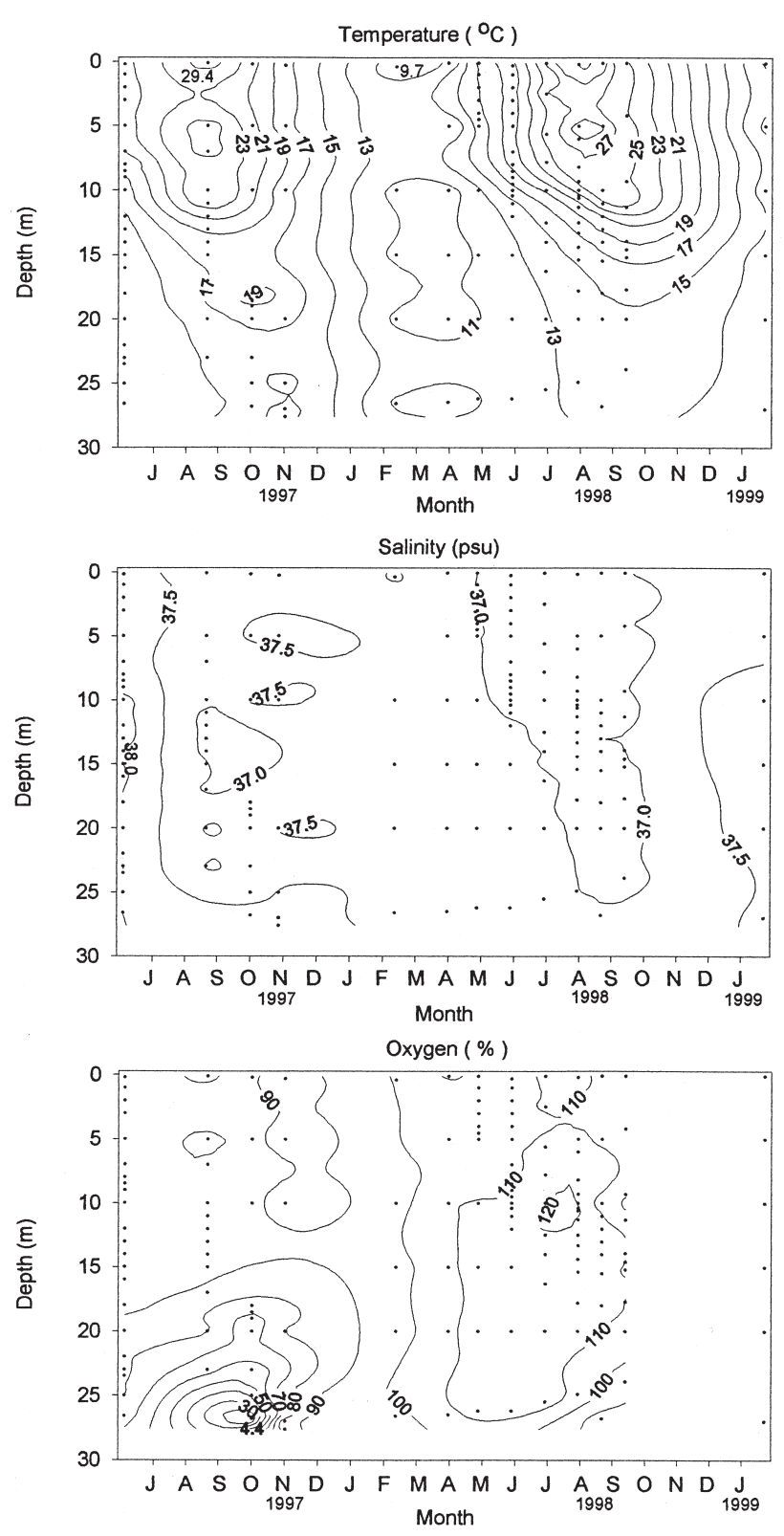

FIG. 2. - Distribution of temperature, salinity and dissolved oxygen in "Malo jezero" (MJ) from June 1997 to January 1999.

extending from the surface to $17 \mathrm{~m}$, temperature was from $26.0^{\circ} \mathrm{C}$ to $23.0^{\circ} \mathrm{C}$, and from $20 \mathrm{~m}$ to the bottom it was $16.0^{\circ} \mathrm{C}$ to $12.5^{\circ} \mathrm{C}$. Salinity values were relatively low, and ranged from 34.9 psu at the surface to $36.7 \mathrm{psu}$ which occurred from $35 \mathrm{~m}$ to the bottom. Within the thermocline layer, slight variations of salinity were noticed. Oxygen saturation values from the surface to $17 \mathrm{~m}$ were between $91 \%$ and $95 \%$, yet in the thermocline layer values slightly increased to the maximum of $101 \%$ at $18.5 \mathrm{~m}$, and thereafter rapidly decreased to $0 \%$ in the layers from $39 \mathrm{~m}$ to the bottom.

Nutrient values (Fig. 4a) in VJ were different in
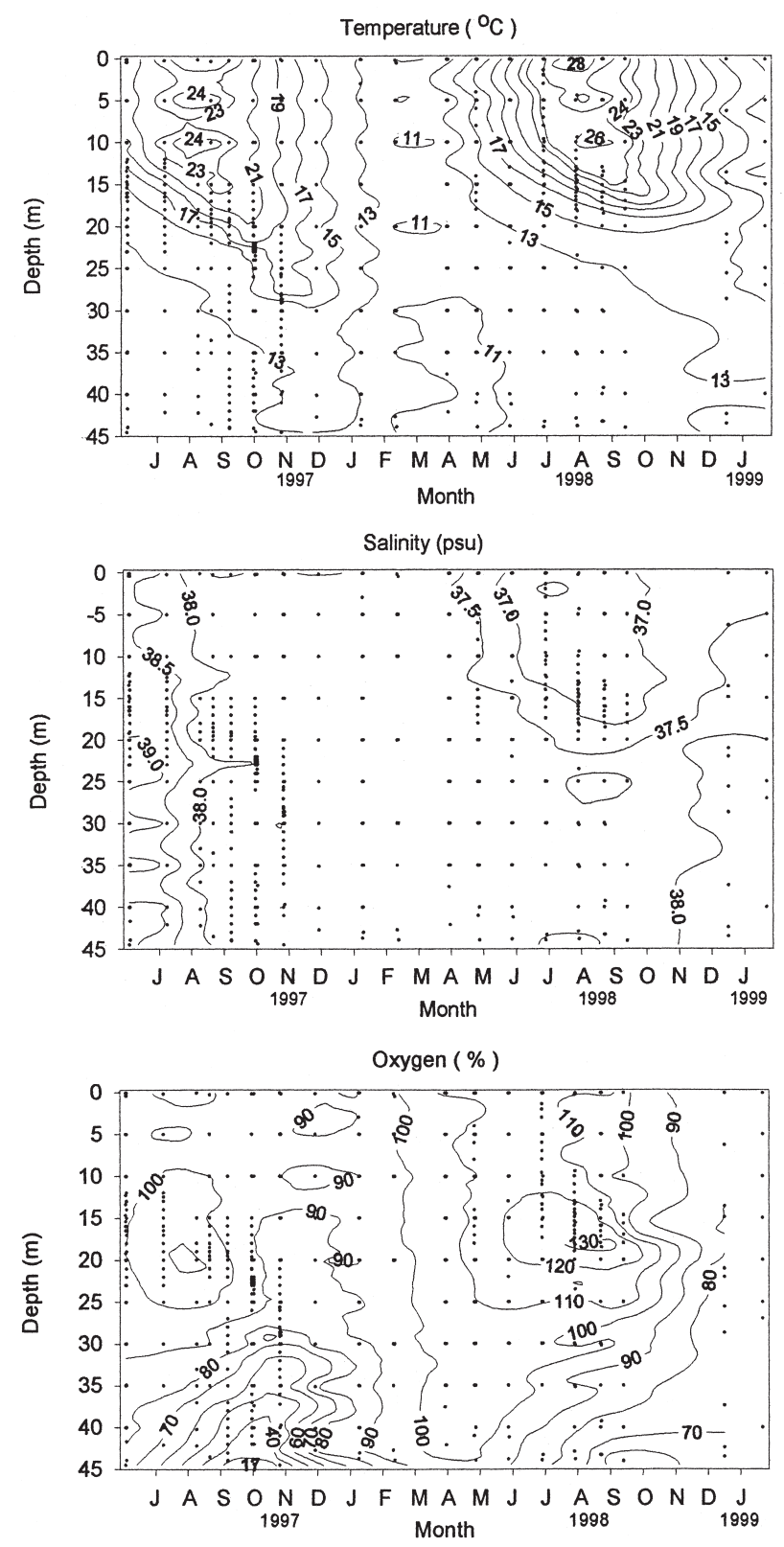

FIG. 3. - Distribution of temperature, salinity and dissolved oxygen in "Veliko jezero" (VJ) from June 1997 to January 1999.

1997 and 1998 and, with the exceptions of reactive silicates, all values were higher in 1998. Statistical significance $(\mathrm{P}<0.01)$ was noted only for differences in ammonia and reactive phosphorus. Ranges of the concentration values in 1997 and 1998 were as following: $\mathrm{NO}_{3}(0.1-3.42 ; 0.01-4.54) ; \mathrm{NO}_{2}(0.01-$ $0.33 ; 0.01-0.62) ; \mathrm{NH}_{4}(0.07-0.33 ; 0.21-1.2) ; \mathrm{N}_{\text {tot }}$ (2.19-7.82; 0.68-32.13); $\mathrm{PO}_{4}(0.01-0.15 ; 0-0.26)$; $\mathrm{SiO}_{4}(0.61-37.99 ; 0.54-28.71)$. In the summer of 1997 and 1998, a pronounced nutricline was present between 20 and $25 \mathrm{~m}$, while during the fall it was noted at depths greater than $30 \mathrm{~m}$. Statistically significant differences $(\mathrm{P}<0.05)$ for concentrations of 

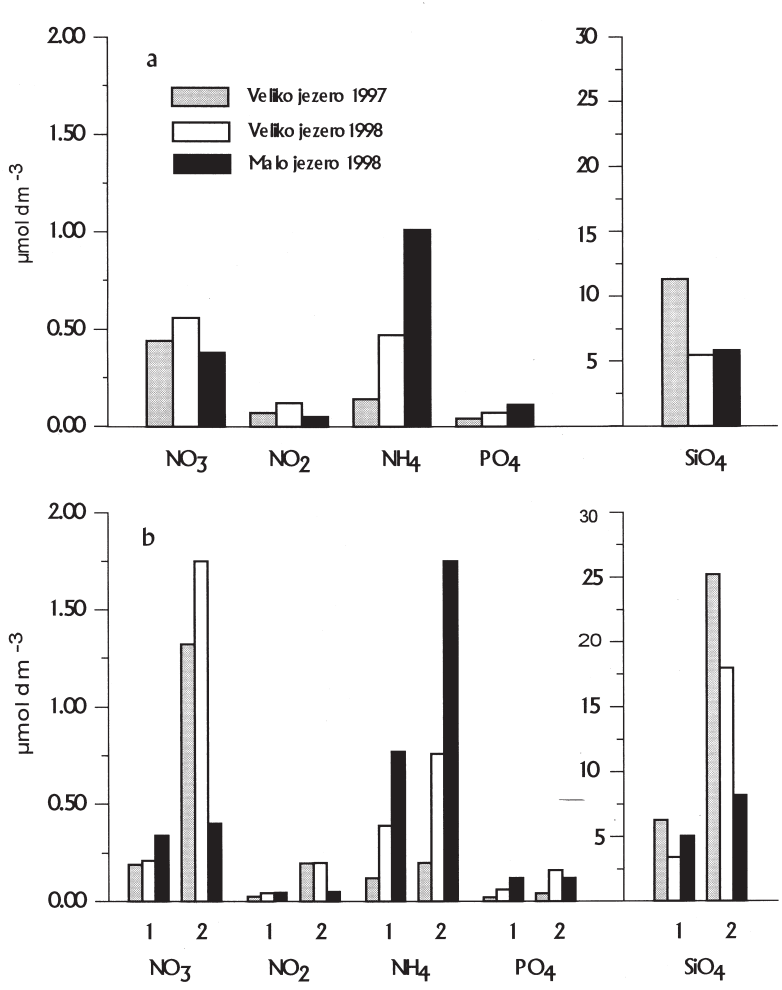

FIG. 4. - Nutrient concentrations during the investigated period in VJ and MJ. Values are expressed as water column mean in (a), and for different layers ( $1=$ above nutricline; $2=$ below nutricline) as mean of layers in (b). nutrients within vertical gradients were noted both years. In layers above and below the nutricline, significant differences $(\mathrm{P}<0.05)$ in concentrations of $\mathrm{NH}_{4}$ and $\mathrm{PO}_{4}$ were noted during periods of strong stratification (Fig. 4b). During the isothermal winter period concentrations of nutrients were homogenous in the entire water column.

In 1998 in $\mathrm{MJ}$, the concentration values for $\mathrm{NO}_{3}$ and $\mathrm{NO}_{2}$ were notably lower than in VJ (Fig. 4). Concentration ranges were as follow: $\mathrm{NO}_{3}(0.04-$ 1.65), $\mathrm{NO}_{2}(0.01-0.15), \mathrm{N}$-tot (0.64-7.21), $\mathrm{SiO}_{4}$ (2.42-11.76). Concentrations of $\mathrm{NH}_{4}(0.46-2.18)$ and reactive phosphorus $(0.03-0.67)$ were significantly higher than in $\mathrm{VJ}(\mathrm{P}<0.01)$. Only the $\mathrm{NH}_{4}$ concentration showed a vertical gradient below $20 \mathrm{~m}$.

There were no differences in mean values of reactive $\mathrm{SiO}_{4}$ for both lakes (Fig. 4), but their vertical distributions were different. In MJ the concentrations of $\mathrm{SiO}_{4}$ were quite equal for the entire water column, but in VJ maximum values were noted in the near bottom layer (Fig. 4b).

A small number of species characterized the zooplankton in both lakes. In VJ most zooplankton density values were less than 5000 ind. $\mathrm{m}^{-3}$ with a maximum of 17097 ind. $\mathrm{m}^{-3}$ in September and minimum of 580 ind. $\mathrm{m}^{-3}$ in November (Fig. 5). The total zoo-

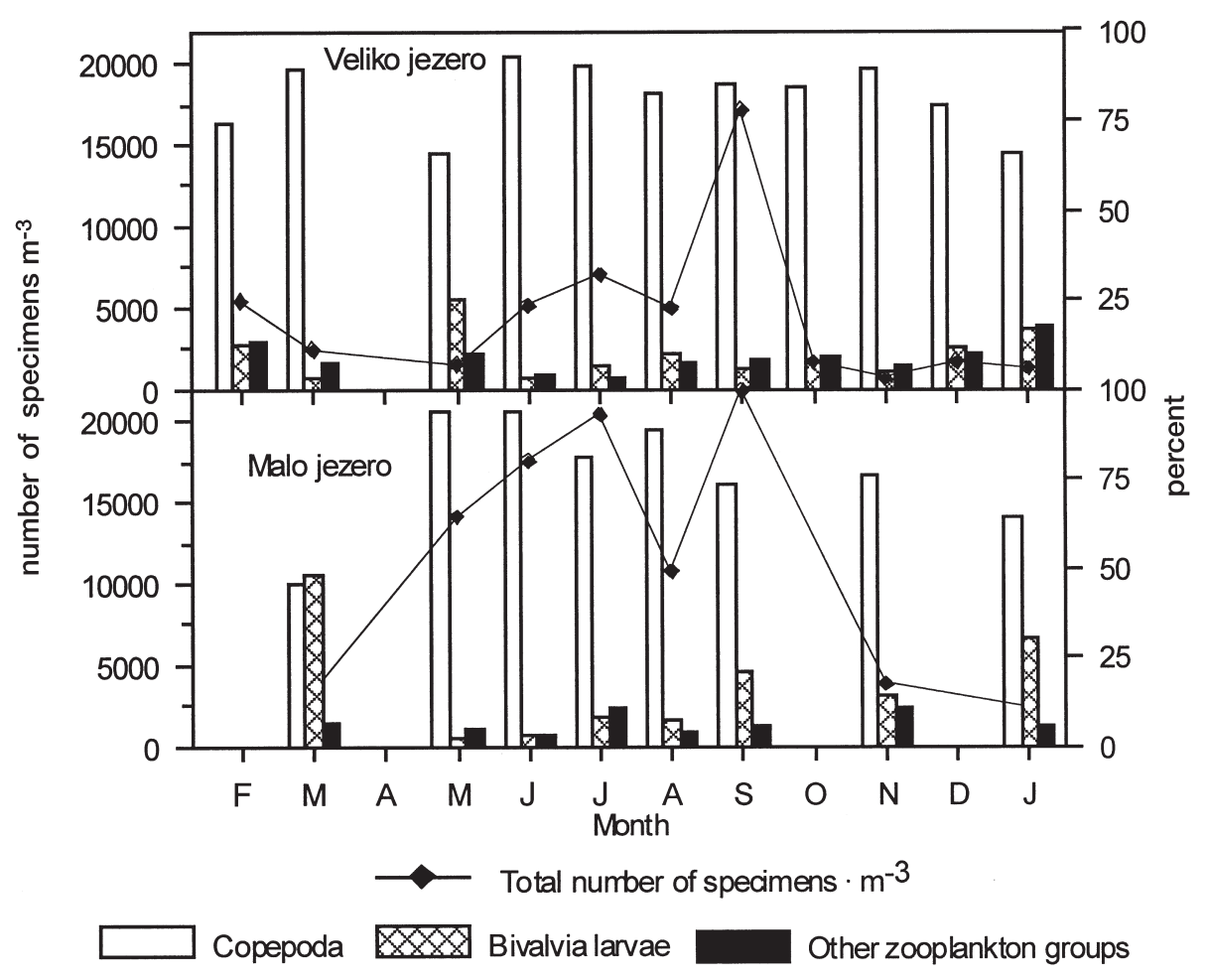

FIG. 5. - Total zooplankton (no. ind. $\mathrm{m}^{-3}$; left-hand scale) and percentage occurrence (right-hand scale) from February 1998 to January 1999 in $\mathrm{VJ}$ and MJ. 
plankton in MJ was high during spring and summer (Fig. 5). In this period, zooplankton density values ranged between 10757 ind. $\mathrm{m}^{-3}$ and 21864 ind. $\mathrm{m}^{-3}$. A minimum of 2275 ind. $\mathrm{m}^{-3}$ was noted in January. Annual averages ratios of copepods to total zooplankton numbers were $82 \%(\mathrm{VJ})$ and $77 \%(\mathrm{MJ})$. Among 22 species of copepod in VJ and 12 species in $\mathrm{MJ}$, the most numerous were copepodites of Oithona nana and Paracalanus parvus, followed by Acartia clausi, Oithona similis, Isias clavipes, and Diaixis pygmaea. In VJ Calanus helgolandicus was present in small numbers throughout the year. Among different copepod groups, cyclopoids had the highest density values (VJ: range 19\%-86\%, average $61.2 \%$; MJ: range $48 \%-82 \%$, average $67.1 \%$ ). They were followed by calanoids (VJ: range $14 \%-62 \%$, average $34.1 \%$; MJ: range $18 \%$ $51 \%$, average $32.5 \%$ ). Poecilostomatoids were recorded only in VJ (range 0\%-10\%, average 2\%) and harpacticoids were the minor group in both lakes (VJ: range 0\%-4\%, average 0.7; MJ: 0\%-1\%, average 0.4).

\section{Medusae}

Hydromedusae were present in both lakes in very small numbers of species and specimens, as indicated by plankton tows (Table 1). Their maximum occurrence was 181 ind. $\mathrm{m}^{-3}$ in September 1998 in VJ, and 81 ind. $\mathrm{m}^{-3}$ in May 1998 in MJ. Two of four species of Anthomedusae were collected in each lake and the same four species of Leptomedusae were present in both lakes, the most frequent and abundant of which was Obelia spp. (maximum: VJ: 140 ind. $\mathrm{m}^{-3}$ September; MJ: 61 ind. $\mathrm{m}^{-3}$ May).

A fifth Leptomedusae, Tima sp. (Fig. 6) was observed and collected by SCUBA divers in both lakes, but was never taken in the plankton samples. This distinctive, large species, with a nearly hemispherical umbrella, fairly thick jelly, well-developed velum, $60-84 \mathrm{~mm}$ bell diameter, and $55-75 \mathrm{~mm}$ bell height was present during summer and autumn, always below the thermocline. This species was more sporadic at VJ while a density of about 3 ind. $\mathrm{m}^{-3}$ (between 17 and $20 \mathrm{~m}$ ) was noted at MJ. Tima sp. was not observed in the central parts of MJ where depth is greater than $20 \mathrm{~m}$. At night, slowly moving individuals were found approximately 1-2 $\mathrm{m}$ above bottom and their exposure to diver's light caused rapid movements in opposite direction from the light. During daylight, Tima sp. moved slowly, touching the bottom with its tentacles and feeding on some particles that were collected. One captured mysid (e.g. Mesopodopsys slabberi) was recognized by a SCUBA diver on a tentacle that was pulled to the mouth.

The scyphozoan Aurelia sp. was present in both lakes throughout the year but its ephyrae were never collected in plankton samples. In VJ Aurelia sp. were always observed in swarms of very large numbers of individuals, with the exception of September 1997. Aurelia sp. density ranged from 10 ind. $\mathrm{m}^{-3}$ to

TABLE 1. - Abundance of hydromedusae collected by plankton net in the seawater lakes "Veliko Jezero" (VJ) and "Malo Jezero" (MJ), June 1997 - January 1999. In April (VJ) and February, April, October and December (MJ) plankton was not collected because of technical problems. (No.ind. $\mathrm{m}^{-3}:+=<1 ; \mathrm{r}=1-10 ; \mathrm{c}=11-50 ; \mathrm{cc}=>50$ ).

\begin{tabular}{|c|c|c|c|c|c|c|c|c|c|c|c|}
\hline Species / Month & $\mathrm{J}$ & F & M & M & $\mathrm{J}$ & $\mathrm{J}$ & A & $\mathrm{S}$ & $\mathrm{O}$ & $\mathrm{N}$ & $\mathrm{D}$ \\
\hline $\begin{array}{l}\text { VJ } \\
\text { ANTHOMEDUSAE }\end{array}$ & & & & & & & & & & & \\
\hline $\begin{array}{l}\text { Podocoryne minima } \\
\text { Podocoryne minuta } \\
\text { LEPTOMEDUSAE }\end{array}$ & & & + & & $\begin{array}{l}\mathrm{c} \\
\mathrm{r}\end{array}$ & $\begin{array}{c}+ \\
\mathrm{r}\end{array}$ & $\mathrm{r}$ & $\mathrm{c}$ & + & $\mathrm{r}$ & $\begin{array}{l}+ \\
+\end{array}$ \\
\hline $\begin{array}{l}\text { Obelia spp. } \\
\text { Clytia hemisphaerica } \\
\text { Eirene viridula } \\
\text { Eutima gracilis }\end{array}$ & $\mathrm{r}$ & $\mathrm{c}$ & $\mathrm{c}$ & + & $\begin{array}{l}c \\
+\end{array}$ & $\mathrm{cc}$ & $\begin{array}{l}\mathrm{cc} \\
\mathrm{r} \\
+ \\
+\end{array}$ & $\begin{array}{l}\mathrm{cc} \\
\mathrm{r} \\
+\end{array}$ & $\begin{array}{c}\mathrm{cc} \\
+\end{array}$ & $\mathrm{r}$ & + \\
\hline $\begin{array}{l}\text { MJ } \\
\text { ANTHOMEDUSAE } \\
\text { Sarsia gemmifera }\end{array}$ & & & $\mathrm{r}$ & & & & & & & & \\
\hline $\begin{array}{l}\text { Bougainvillia muscus } \\
\text { Podocoryne minima } \\
\text { Podocoryne minuta } \\
\text { LEPTOMEDUSAE }\end{array}$ & & $\mathrm{r}$ & $\mathrm{c}$ & & $\begin{array}{l}\mathrm{r} \\
\mathrm{c}\end{array}$ & $\mathrm{r}$ & $\begin{array}{l}\mathrm{r} \\
\mathrm{c}\end{array}$ & $\mathrm{r}$ & & & \\
\hline $\begin{array}{l}\text { Obelia spp. } \\
\text { Clytia hemisphaerica } \\
\text { Eirene viridula } \\
\text { Eutima gracilis }\end{array}$ & $\mathrm{r}$ & $\mathrm{r}$ & $\mathrm{cc}$ & & $\mathrm{c}$ & $\mathrm{c}$ & + & $\begin{array}{l}+ \\
c \\
+\end{array}$ & & $\mathrm{c}$ & \\
\hline
\end{tabular}




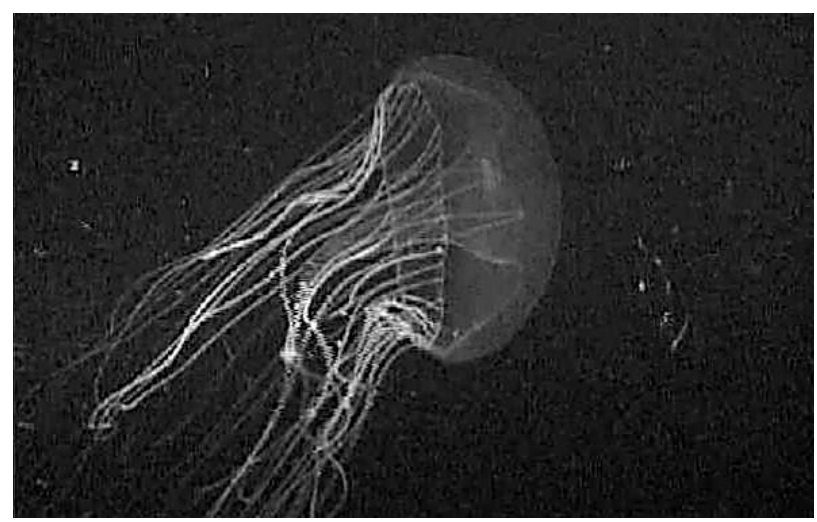

Fig. 6. - Tima sp. swimming horizontally near the bottom at $17 \mathrm{~m}$ in MJ. Photo by V.Onofri at 10.00 p.m., August 1998.

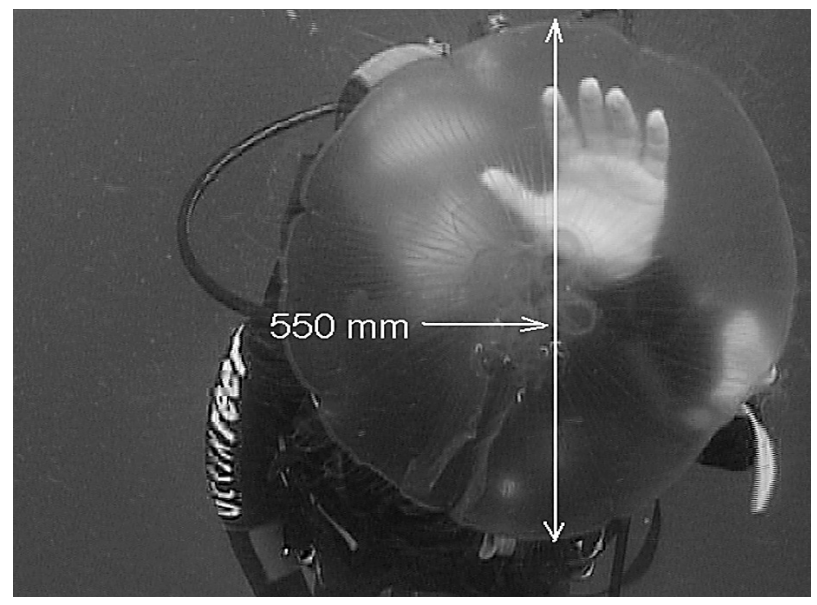

FIG. 7. - The largest Aurelia sp. specimen observed at $22 \mathrm{~m}$ in MJ. Photo by V. Onofri at 2.00 p.m., July 1998.

approximately more than 600 ind. $\mathrm{m}^{-3}$. Diameter of the swarm was typically about $150 \mathrm{~m}$. Horizontal movements of the entire swarm were observed as well as the active swimming of individuals toward the center of the swarm. Density of Aurelia sp. was always higher when the swarm was concentrated in either surface or deep layers. Within the swarm an especially high number of smaller aggregations of individuals were observed (e.g. from a small aggregation, 80 individuals were collected in a 20 -liter container). Strong vertical migrations were noted. In summer months swarms were concentrated above the thermocline during the daylight, and below the thermocline at night. In winter months swarms were distributed unequally during the daylight, concentrating near the surface at dawn and sunset, migrating to deep layers after sunset and concentrating in deep layers through the night. Diameter of individuals was between $10 \mathrm{~mm}$ (December 1998) and 120 mm. During the anoxic event on 26-28 August 1996, the Aurelia sp. swarm, with specimens quiescent or only slowly moving, was observed just above the anoxic layer.

In MJ Aurelia sp. were distributed randomly. Though more individuals were always noted in the deeper layers (cca. from 17-25 m) and in the central part of the lake, neither vertical migrations nor swarms were observed. Individual numbers were from 1 to 10 ind. $100 \mathrm{~m}^{-3}$, approximately. Diameters of these individuals were between $100 \mathrm{~mm}$ and the maximum of $550 \mathrm{~mm}$ (Fig. 7).

\section{DISCUSSION AND CONCLUSIONS}

Ecological characteristics of the Mljet Island seawater lakes are influenced by the surrounding terrestrial area and by restricted communication with the open sea through the naturally-formed shallow strait. Similar effects have been described in Ireland for Lough Hyne (Ballard and Myers, 1996). The longtime isolation of the Mljet lakes (Schmidt, 1993) has probably caused their specific environmental conditions and influenced the persistence of the primitive Tethys fauna that is known for some parts of Mediterranean Sea (Gili et al., 1998). It is well known that coastal environments are subjected to intensive changes of hydrographic conditions depending on local atmospheric and other coastal influences. The stratification is pronounced during summer months when a very strong thermocline divides the water columns and influences all hydrographic, chemical and biologic parameters (Buljan and Špan, 1976; Kršinić and Lučić, 1994; Benović and Onofri, 1995; Carić and Jasprica, 1998). Though general ecological conditions are similar in both lakes, some important differences should be noted. While in MJ the summer thermocline appears between 10 and $15 \mathrm{~m}$, in $\mathrm{VJ}$ it is deeper, at $15-20 \mathrm{~m}$. The influx of hyperhaline waters from the surrounding sea to the VJ that was noted in June-July 1997 has only slightly influenced the salinity values of MJ.

The consequences of the pronounced thermocline include constantly lower temperatures at depth (in layers 20-45 m) than in the surrounding sea at the same depth. This probably causes persistence of specific communities in deeper layers of both lakes (Kršinić and Lučić, 1994; Onofri and Marguš, 1995; Vučetić, 1995). Since in both lakes there are no upwellings or other forces to exchange waters from the bottom layers to the surrounding sea, we believe that the ecology in layers below the thermocline maintains primordial entities, beginning with an influx of waters from 4200 or 7000 years ago (M. 
Juračić and V. Onofri, unpublished; Schmidt, 1993).

The nutrient water column profile in VJ generally shows lower values in upper layers (Carić and Jasprica, 1998). It could be supposed that the typical trophic relationship between nutrients and phytoplankton exists in upper zones of VJ. In deeper zones, and especially in near-bottom layers, higher nutrient concentrations might be related to excretions from the Aurelia swarms (Schneider, 1989) and other zooplankton aggregations (Kršinić and Lučić, 1994; Benović and Onofri, 1995), as well as to sinking of organic matter and its decomposition (Azam, et al., 1983). In MJ, nutrient concentrations were homogenous throughout the entire water column. However, a vertical gradient for $\mathrm{NH}_{4}$ concentrations is shown below $20 \mathrm{~m}$. It is important to note than during this survey these concentrations of $\mathrm{NH}_{4}$ were notably higher than averages elsewhere in the coastal and open southern Adriatic (M. Carić, pers. comm.). These concentrations could be related to the large number of big Aurelia (Schneider, 1989) permanently present in the deeper layers of MJ.

Anoxic conditions occasionally occur in deep layers of closed marine ecosystems (Buljan, 1956; Buljan and Špan, 1976; Ballard and Myers, 1996). In VJ anoxic conditions were noted for the first time on 27 and 28. August 1996 when brief anoxia occurred in the layer below $35 \mathrm{~m}$. It is possible that similar anoxic conditions appear regularly in $\mathrm{VJ}$ during periods of the strongest stratification, but because of short duration they can readily be missed. The formation of anoxic conditions is mostly related to bacterial activity and the decomposition of organic compounds (Azam et al., 1983), but presence of large numbers of Aurelia near the anoxic layer (Thuesen and Childress, 1994) could also be a substantial contributing factor (Hansson and Norrman, 1995). It is possible that marine snow also plays an important part in ecological processes of the lakes (Ott and Herndl, 1995). In VJ, in layers above the thermocline, concentrations of marine bacteria are in concentrations similar to those of highly productive coastal areas (S. BobanovićColić, pers. comm.). Especially high bacteria concentrations that are temporarily found in near bottom layers (i.e. in 1988: range of $0.35 \times 10^{6} \mathrm{ml}^{-1}$ to $8.34 \times 10^{6} \mathrm{ml}^{-1}$, S. Bobanović-Ćolić, pers. comm.) are usually characteristic only for extremely eutrophicated areas (Azam et al., 1983; Ducklow, 1983). Decomposition processes induced by very high numbers of bacteria provide a probable reason for high concentrations of silicates in the VJ near- bottom layers, while large numbers of randomly distributed Aurelia in MJ probably caused higher concentrations of ammonia there (Schneider, 1989).

According to Viličić (1989) categorizing ecosystems on the basis of the phytoplankton population density and biomass, the Mljet lakes would be a "moderately eutrophicated ecosystem". Similar annual average phytoplankton population densities have been recorded in highly productive south Adriatic coastal zones (Jasprica, 1989). In the spring of 1986 an atypical seasonal phytoplankton succession was noted, similar to what is known to occasionally appear in the coastal Adriatic areas (Viličić et al., 1995; Jasprica and Carić, 1997), and in the Mediterranean (Carrada et al., 1980). Higher Chl $a$ concentration in deeper zones of VJ could be explained by the high percentage of the nanophytoplankton fraction (Jasprica and Carić, 1997), sinking of particles (Ott and Herndl, 1995) and moderate metabolic processes of zooplankton due to the constantly low temperatures (Carić and Jasprica, 1995).

The zooplankton of similar ecosystems is typically characterized by domination by very few species that are occasionally present in very high densities (Raymont, 1983). Both of the Mljet lakes are inhabited by small numbers of zooplankton species and are dominated by calanoid and cyclopoid copepodites (Paracalauns parvus and Oithona nana). Copepods are permanently separated in the water column: copepodites and smaller species (i.e. P. parvus; $O$. nana) were always more abundant near the surface and above thermocline, and adults of larger species (i.e. C. helgolandicus) below the thermocline (Vučetić, 1995), aggregating in deeper layers (Kršinić and Lučić, 1994). As in the results of previous studies, one of the most abundant Adriatic-calanoids, Pseudocalanus elongatus (Vučetić, 1957; Kršinić and Lučić, 1994) was not present in our samples. In MJ the zooplankton densities were constantly higher than in VJ (except in September 1998), especially during spring and summer months. These results correspond to the distribution and abundance of Aurelia sp. medusae. In other ecosystems similar to the Mljet lakes, medusae are abundant and present with high numbers of zooplankton species (Ballard and Myers, 1996).

In the present study we noted very low numbers of hydromedusae, representing only the Anthomedusae and Leptomedusae. We found only seven species in VJ and nine species in MJ, with only Obelia spp. and Tima sp. being present over long periods. In surrounding areas of the southern Adri- 
atic, representatives of all hydromedusan orders are present and the majority of specimens have been identified as the trachymedusae Rhopalonema velatum, Aglaura hemistoma and Liriope tetraphylla (Benović, 1976). None of these common species were collected in the present study in Mljet lakes, while Vučetić (1957) found only two of them more than 40 years before our study. Lučić and BenderPojatina (1995) found eight hydromedusan species in $\mathrm{VJ}$, including a few individuals of A. hemistoma and $R$. velatum, shortly before our study.

For the first time in the Adriatic Sea since the studies of Neppi and Stiasny (1913), specimens from the genus Tima are reported. We designate these animals as Tima sp. because identification could not be precisely determined to the species level, but the genus has been confirmed to be Tima (S. Kubota, pers.comm.). The only Tima species previously known from the Mediterranean Sea is the rare Tima luculana (Mayer, 1910, Vannucci, 1966, Brinckmann-Voss, 1987, Gili et al., 1988). Our results differ from earlier records of T. luculana in the number of specimens, large size of individuals and frequency of appearance observed by the specialist SCUBA diver. Probably, this species has not been frequently collected elsewhere because of its very fragile body structure that results in disintegration of any individuals collected by standard plankton net sampling. The very restricted near-bottom areas of its distribution would increase the unlikeliness of collecting this species with standard techniques. The probable permanent presence and apparent abundance of Tima in the Mljet lakes may imply a relationship to the putative primitive Tethys fauna found elsewhere in deep pockets in the Meditrerranean (Gili et al., 1998). Future studies should determine whether the Tima sp. present in the Mljet lakes is Tima luculana or represents a new near-bottom species in an unusual habitat.

The presence of great numbers of Aurelia sp. medusae, usually identified as A.aurita, is a worldwide phenomena, distributed approximately between $70^{\circ} \mathrm{N}$ and $40^{\circ} \mathrm{S}$ (Kramp, 1961). In temperate zones, Aurelia medusae appear in masses during spring-summer, and reproduce from December onward (Lucas, 1996). On the contrary, swarms of Aurelia in VJ and randomly distributed big individuals in MJ were present throughout the year, but were never found in the surrounding open Adriatic (Benović and Bender, 1987). This may be related to the permanently low temperature values in the deeper layers of both lakes and thermal requirements for strobilation (Omori et al., 1995).

We identify our species as Aurelia sp. because recent studies do not confirm this species to be the same as A. aurita. Analyses by W. Schroth and B. Schierwater, Zoologisches Institut, Frankfurt am Main, Germany (pers.comm.) provide compelling molecular evidence (nuclear and mitochondrial DNA sequence analyses) that Aurelia sp. from Mljet lakes substantially differs in terms of genetic divergence from Aurelia aurita found elsewhere in the Mediterranean, and could be attributed to its boreal origin. In previous plankton studies of the Mljet lakes (Vučetić, 1957; Lučić and Bender-Pojatina, 1995) Aurelia was noted throughout the year, but only sporadically. Local fishermen from the island of Mljet regularly observe Aurelia swarms during low atmospheric pressure on cloudy and drizzling days at the surface of VJ. This phenomenon is known to occur in other shallow ecosystems and has been related to the particular light intensity (Yasuda, 1970). The numbers and sizes of Aurelia individuals in the Mljet lakes are greater than reported in other parts of the world (Yasuda, 1970, Olesen, et al., 1994, Lucas, 1996). Our specimens with the bell diameter of $550 \mathrm{~mm}$ from MJ (Fig. 7) were bigger than the maximum known diameter of $500 \mathrm{~mm}$ observed in the La Plata river mouth (H. Mianzan, Mar del Plata, Argentina, pers. comm.) We believe that the constantly decreasing value of zooplankton abundance, low number of hydromedusae, and disappearance of certain plankton copepod species (Pseudocalanus elongatus) is the consequence of the impact of Aurelia swarms and their selective feeding (Behrends and Schneider, 1995, Omori et $a l .$, 1995). Though Tima sp. is not present in masses, it also has an important impact because it inhabits different parts of the lakes than Aurelia does. The noticeably larger Aurelia individuals in MJ than in $\mathrm{VJ}$ are apparently in direct relationship with higher food availability (Mills, 1995; Ishii and Bamstedt, 1998). It is hypothesized that MJ contains only imported medusae from $\mathrm{VJ}$, since the absence of ephyrae, and swarms and random distribution may be interpreted as indicating that Aurelia probably do not form scyphistomae in MJ, where the high sedimentation rate (Juračić et al., 1995) and occasional appearance of $\mathrm{H}_{2} \mathrm{~S}$ (Buljan, 1956) may prevent settlement of scyphistomae. The high nutrient concentrations, high bacterial and phytoplankton values, lower abundance of zooplankters and anoxia in VJ designate the Mljet lakes as a potentially highly vulnerable ecosystem. Our results indicate that the 
Aurelia sp. medusae play a crucial role in maintenance of this sensitive boreal ecosystem. Because of the long isolation of the Mljet lakes, we believe that the same processes have determined ecosystem stability from early ages.

\section{ACKNOWLEDGEMENTS}

This work was supported by the Ministry for Science and Technology of Croatia. We express our gratitude to the head of the National park "Mljet" for giving us technical support and to S. Kubota, $\mathrm{H}$. Mianzan, W. Schroth and B. Schierwater for their valuable contributions and comments on the manuscript.

\section{REFERENCES}

Azam, F., T. Fentchel, J. G. Field, J. S. Gray, L. A. Meyer-Reil and F. Thingstad. - 1983. The ecological role of water-column microbes in the sea. Mar. Ecol. Prog. Ser., 10: 257-263.

Ballard L. and A. Myers. - 1996. Seasonal changes in the vertical distribution of five species of the family Bougainvilliidae (Cnidaria: Anthomedusae) at Lough Hyne, south-west Ireland. Sci. Mar., 60: 69-74.

Benović, A. - 1976. Hydromedusae (Cnidaria) from two stations in the Southern Adriatic and Tyrrhenian Seas in the year 19671968. Pubbl. Stat. Zool. Napoli, 40: 1-10.

Benović, A. and A. Bender. - 1987. Seasonal distribution of medusae in the Adriatic Sea. In: J. Bouillon, F. Boero, F. Cicogna and P.F.S. Cornelius (eds.), Modern trends in the systematics, ecology and evolution of hydroids and hydromedusae, pp. 117-131. Oxford Univ. Press.

Benović, A. and D. Lučić. - 1996. Comparison of hydromedusae findings in the northern and southern Adriatic Sea. Sci. Mar., 60: $129-135$.

Benović, A. and V. Onofri. - 1995. Ecological peculiarity of the Big Lake on the Island of Mljet. In: P. Durbešić and A. Benović (eds.), Simpozij "Prirodne značajke i društvena valorizacija otoka Mljeta”, Pomena 4-10.9.1995. pp. 511-521. Hrvatsko Ekološko Društvo, Zagreb.

Behrends, G. and G. Schneider. - 1995. Impact of Aurelia aurita medusae (Cnidaria, Scyphozoa) on the standing stock and community composition of mesozooplankton in the Kiel Bight (wester Baltic Sea). Mar. Ecol. Prog. Ser., 127: 39-45.

Brinckmann-Voss, A. - 1987. Seasonal distribution of hydromedusae (Cnidaria, Hydrozoa) from the Gulf of Napoli and vicinity, with observations of sexual and asexual reproduction in some species. In: J. Bouillon, F. Boero, F. Cicogna and P.F.S. Cornelius (eds.), Modern trends in the systematics, ecology and evolution of hydroids and hydromedusae, pp. 133-141. Oxford Univ. Press.

Buljan, M. - 1956. Prvi nalazi sumporovodika $\left(\mathrm{H}_{2} \mathrm{~S}\right)$ u vodi Jadrana. Mornarički glasnik, 6: 207-214.

Buljan, M. and J. Špan. - 1976. Hydrographical properties of the sea water "Lakes" on the island of Mljet and adjoining sea in the eastern south Adriatic Sea. Acta Adriat., 6: 1-224.

Carić, M. and N. Jasprica. - 1995. The concentration of nutrients and chlorophyll $a$ in Veliko jezero during the stratification period (1990). In: P. Durbešić and A. Benović (eds.): Simpozij "Prirodne značajke $i$ društvena valorizacija otoka Mljeta", Pomena 4-10.9.1995. pp. 447-451. Hrvatsko Ekološko Društvo, Zagreb.

Carić, M. and N. Jasprica. - 1998. Seasonal variability of nutrient and chlorophyll $a$ concentrations in the karstic coastal lake Veliko Jezero (Mljet Island, Adriatic Sea). Rapp. Comm. Int.
Mer Médit., 35: 238-239.

Carrada, G.C., T.S. Hopkins, G. Bonaduce, A. Ianora, D. Marino, M. Modigh, M. Ribera d'Alcala amd B. Scotto di Carlo. - 1980. Variability in the hydrographic and biological features of the Gulf of Naples. P.S Z.N.: Mar. Ecol., 1: 105-120.

Ducklow, H. W. - 1983. Production and fate of bacteria in the oceans. Bioscience, 33: 494-501.

Ercegović, A. - 1935. Une contribution á la connoissance des conditions hydrographiques et biologiques du lac de l'ille de Mljet (Méléda). Acta Botanica. 10: 50-60.

Gili, J. M., J. Bouillon, F. Pages, A. Palanques, P. Puig and S. Heussner. - 1998. Origin and biogeography of the deep-water Mediterranean Hydromedusae including the description of two new species collected in submarine canyons of Northwestern Mediterranean. Sci. Mar., 62: 113-134.

Gili, J. M., F. Pages, A. Sabates and J. D. Ros. - 1988. Small-scale distribution of a cnidarian population in the western Mediterranean. J. Plankton Res., 10: 385-401.

Grasshoff, K., F. Erhardt and K. Kremling. - 1983. Methods of seawater analysis. $2^{\text {nd }} \mathrm{Ed}$. Verlag Chemie, Weinheim.

Hansson, L. J. and B. Norrman. - 1995: Release of dissolved organic carbon (DOC) by the scyphozoan jellyfish Aurelia aurita and its potential influence on the production of planktic bacteria. Mar. Biol., 121: 527-532.

Hure, J. and F. Kršinić. - 1998. Planktonic copepods of the Adriatic Sea. Nat. Croat., 7 Suppl. 2: 1-135.

Ishii, H. and U. Bamstedt. - 1998. Food regulation of growth and maturation in a natural populations of Aurelia aurita (L.). $J$. Plankton Res., 20: 805-816.

Jasprica, N. - 1989. Distribution of the phytoplankton population density and volume-biomass in the Mali Ston and Gruž bays (Southern Adriatic). Ekologija. 24:83-96.

Jasprica, N. and M. Carić. - 1997. A comparison of phytoplankton biomass estimators and their environmental correlates in the Mali Ston Bay (Southern Adriatic). P.S.Z.N.: Mar. Ecol., 18: $35-50$.

Juračić, M., I. Sondi, D. Barišić, N. Vidović and V. Pravdić. - 1995. Sedimenti i sedimentacija u mljetskim jezerima (Hrvatska). In: P. Durbešić and A. Benović (eds.), Simpozij "Prirodne značajke i društvena valorizacija otoka Mljeta", Pomena 410.9.1995. pp. 107-116. Hrvatsko Ekološko Društvo, Zagreb.

Kramp, P.L. - 1961. Synopsis of the medusae of the world. J. Mar. Biol. Ass. U. K., 40: 1-469.

Kršinić, F. - 1998. Vertical distribution of protozoan and microcopepod communities in the South Adriatic Pit. J. Plankton Res., 20: 1033-1060.

Kršinić, F. and D. Lučić. - 1994. Mesozooplankton sampling experiments with the "Adriatic" sampler: differences of catch between 250 and $125 \mu \mathrm{m}$ mesh netting gauze. Estuar. Coast. Shelf Scien., 38: 113-118.

Lucas, C. H. - 1996. Population dynamics of Aurelia aurita (Scyphozoa) from an isolated brackish lake, with particular references to sexsual reaproduction. J. Plankton Res., 6: 987-1007.

Lučić, D. and A. Bender-Pojatina. - 1995. Net zooplankton of Mljet lakes. In: P. Durbešić and A. Benović (eds.), Simpozij "Prirodne značajke i društvena valorizacija otoka Mljeta", Pomena 4-10.9.1995. pp. 483-498. Hrvatsko Ekološko Društvo, Zagreb.

Mayer, A.G. - 1910. Medusae of the world. Carnegie Institution, Washington. 498 pp.

Mills, C.E. - 1995. Medusae, siphonophores, and ctenophores as planktivorous predators in changing global ecosystems. ICES J. Mar. Sci., 52: 575-581.

Neppi, V. and G. Stiasny. - 1913. Die Hydromedusen des Golfes von Triest. Arb. Zool. Inst. Univ. Wien, 20: 23-92.

Olesen, N.J. - 1995. Clearance potential of jellyfish Aurelia aurita, and predation impact on zooplankton in s shallow cove. Mar. Ecol. Prog. Ser., 124: 63-72.

Olesen, N.J., K. Frandsen and H.U. Riisgard. - 1994. Population dynamics, growth and energetic of jellyfish Aurelia aurita in a shallow fjord. Mar. Ecol. Prog. Ser., 105: 9-18.

Omori, M., H. Ishii and A. Fujinaga. - 1995. Life history strategy of Aurelia aurita (Cnidaria, Scyphomedusae) and iots impact on the zooplankton community of Tokyo Bay. ICES J. Mar. Sci., 52: 597-603.

Onofri, V. and D. Marguš. - 1995. Biology of the scallop (Pecten jacobaeus L.) and rearing possibilities in the Mljet area. In: P. Durbešić and A. Benović (eds.): Simpozij "Prirodne značajke $i$ 
društvena valorizacija otoka Mljeta”, Pomena 4-10.9.1995. pp. 555-562. Hrvatsko Ekološko Društvo, Zagreb.

Ott, J.G. and G.J. Herndl. - 1995. Gelatinous aggregates in the northern Adriatic sea. Bull. Inst. oceanogr., Monaco, $n^{o}$ special, 15: 133-147.

Raymont, J.E.G. - 1983. Plankton and productivity in the oceans. $2^{\text {nd }}$ Ed. Zooplankton. Pergamon Press, New York. 824 pp.

Schmidt, R. - 1993. Environmental changes in two Adriatic coastal lakes in the time interval 7.500 - 5.000 B.P (Atlantic) with special reference to the diatom succession of Cyclotella. Limnologica, 23: 47-58.

Schneider, G. - 1989. The common jellyfish Aurelia aurita: standing stock, excretion and nutrient regeneration in the Kiel Bight, Western Baltic. Mar. Biol., 100: 507-514.

Seibold, E. - 1958. Jahreslagen in Sedimenten der mittleren Adria. Geologische Rundschau, 47: 100-117.

Shushkina, E.A. and E.I. Musayeva, - 1983. The role of jellyfish in the energy system of Black Sea plankton communities. Oceanology, 23: 92-96.

Strickland, J.D.H. and T.R. Parsons. - 1972. A practical handbook of sea water analyses. Bull. Fish. Res. Bd. Canada, 167: $310 \mathrm{pp}$.

The POEM Group. - 1992. General circulation of the Eastern Mediterranean. Earth Science Rev., 32: 285-309.

Thuesen, E.V. and J.J. Childress. - 1994. Oxygen consumption rates and metabolic enzyme activities of oceanic California medusae in relation to body size and habitat depth. Biol. Bull., 187: 84-98.

Vannucci, M. - 1966. Total net plankton volume and hydromedusae from fixed stations in the Gulf of Napoli. In: H. Barnes (ed.),
Some contemporary studies in Marine Science. pp. 675-697. Allen and Unwin, London.

Viličić, D. - 1985. A phytoplankton study of southern Adriatic waters near Dubrovnik for the period from June 1979 to July 1980. CENTRO, 1/2: 35-56.

Viličić, D. - 1989. Phytoplankton population density and volume as indicators of eutrophication in the eastern part of the Adriatic Sea. Hydrobiologia, 174: 117-132.

Viličić, D. - 1991. A study of phytoplankton in the Adriatic Sea after the July 1984 bloom. Int. Revue ges. Hydrobiol., 76: 197211.

Viličić, D., F. Kršinić, M. Carić, N. Jasprica, S. Bobanović-Ćolić and J. Mikuš. - 1995. Plankton and hydrography in a moderately eutrophicated eastern Adriatic Bay (Gruz Bay). Hydrobiol., 304: 9-22.

Vučetić, T. - 1957. Zooplankton investigations in the sea water lakes "Malo Jezero" and "Veliko Jezero" on the island of Mljet (1952-1953). Acta Adriat., 6: 1-52.

Vučetić, T. - 1995. Oceanographic investigation of the Small and the Big Lake on the Island of Mljet - Historical Review. In: P. Durbešić and A. Benović (eds.), Simpozij "Prirodne značajke $i$ društvena valorizacija otoka Mljeta”, Pomena 4-10.9.1995. pp. 401-413. Hrvatsko Ekološko Društvo, Zagreb.

Yasuda, T. - 1970. Ecological Studies on the Jelly-fish, Aurelia aurita (L.) in Urazoko Bay, Fukui Prefecture - V. Vertical distribution of the Medusa. Ann. Rep. Noto Mar. Lab., 10: 15-22.

Zore-Armanda, M., M. Bone, V. Dadić, M. Morović, D. Ratković, L. Stojanovski and I. Vukadin. - 1991. Hydrographic properties of the Adriatic Sea. Acta Adriat., 32: 5-540. 